\title{
THE SUPPORT NETWORK IN PREGNANCY AND CHILDBIRTH: THE CONCEPTIONS OF WOMEN WITH PHYSICAL DISABILITY ${ }^{1}$
}

\author{
Camila Fernandes da Silva Carvalho ${ }^{2}$, Rosineide Santana de Brito ${ }^{3}$
}

\begin{abstract}
${ }^{1}$ Article resulting from the dissertation - Conceptions of women with a physical disability regarding motherhood, presented to the Programa de Pós-Graduação em Enfermagem (PPGENF) of the Universidade Federal do Rio Grande do Norte (UFRN), in 2014.

${ }^{2}$ M.Sc. in Nursing. Scholarship student of the CNPq. Natal, Rio Grande do Norte, Brazil. E-mail: camilafscarvalho@gmail.com

${ }^{3}$ Ph.D. in Nursing. Professor of the PPGENF/UFRN. Natal, Rio Grande do Norte, Brazil. E-mail: rosineide@ufrnet.br
\end{abstract}

\begin{abstract}
This study aimed to investigate the conception of women with physical disability regarding the support network for the exercising of motherhood. It is descriptive-exploratory research, with qualitative approach, whose data were collected through semistructured interviews with 12 women with physical disability, undertaken between April and June 2014. The technique of thematic analysis was used for the treatment of the information, and Symbolic Interactionism was used as the theoretical framework. The interviewees reported the importance of the support of the partner, of family members, and of health professionals, during pregnancy and the postpartum, for them to be able to exercise the maternal role. The absence of this support influenced their conceptions regarding their capacity in this function. One can observe the need to promote the reproductive health of the person with a disability, so as to mitigate the stigmas and thus provide them with appropriate support. In addition to this, the health professionals must be trained to understand holistically their needs and rights. DESCRIPTORS: Nursing. Reproductive health. Disabled persons.
\end{abstract}

\section{REDE DE APOIO NO CICLO GRAVÍDICO-PUERPERAL: CONCEPÇÕES DE MULHERES COM DEFICIÊNCIA FÍSICA}

RESUMO: Este estudo objetivou compreender a concepção de mulheres com deficiência física sobre a rede de apoio para o exercício da maternidade. Pesquisa descritivo-exploratória, de natureza qualitativa, cujos dados foram coletados por meio de entrevista semiestruturada com 12 mulheres com deficiência física, realizada entre abril e junho de 2014. Utilizou-se a técnica de análise temática para o tratamento das informações e o Interacionismo Simbólico como referencial teórico. As entrevistadas relataram a importância do suporte do companheiro, de familiares e profissionais de saúde, durante o ciclo gravídico-puerperal, para que pudessem exercer o papel materno. A ausência de tal apoio influenciou na concepção quanto a sua capacidade nessa função. Observa-se a necessidade de promover a saúde reprodutiva da pessoa com deficiência, de modo a amenizar os estigmas, fornecendo-lhe o suporte adequado. Além disso, os profissionais de saúde devem estar capacitados para compreender holisticamente suas necessidades e direitos.

DESCRITORES: Enfermagem. Saúde reprodutiva. Pessoas com deficiência.

\section{RED DE APOYO EN EL EMBARAZO Y EL PARTO: CONCEPCIONES DE LAS MUJERES CON DISCAPACIDAD FÍSICA}

RESUMEN: Este estudio objetivó comprender la concepción de mujeres con discapacidad física sobre la red de apoyo para el ejercicio de maternidad. Investigación exploratoria y descriptiva, con abordaje cualitativo, cuyos datos fueron recogidos a través de entrevista semiestructurada con 12 mujeres con discapacidad física, realizadas entre abril y junio 2014. Se utilizó la técnica de análisis temático para el tratamiento de los datos y el Interaccionismo Simbólico como marco teórico. Las entrevistadas informaron sobre la importancia de los apoyos de pareja, familiares y profesionales de salud durante la gestación hasta puerperio, para ejercer su papel maternal. La ausencia de este apoyo influye en su concepción sobre su capacidad en esta función. Se observa la necesidad de promover salud reproductiva de personas con discapacidad con el fin de disminuir el estigma y proporcionarlas el apoyo adecuado. Además, los profesionales de salud deben ser capaces de comprender holísticamente sus necesidades y derechos.

DESCRIPTORES: Enfermería. Salud reproductiva. Personas con discapacidad. 


\section{INTRODUCTION}

The demographic census undertaken in 2010 indicated there to be in Brazil approximately 45.6 million persons with some degree of disability. Of this contingent, approximately $50 \%$ are female. ${ }^{1}$ However, the current information system continues to present weaknesses relative to women with disabilities who are in reproductive age in Brazil. As a result, one can understand that the absence of the above-mentioned data may hinder the development of specific governmental initiatives for these women during pregnancy and the postpartum.

The vulnerability of the woman with a disability is also evidenced in the family context, as their family members may believe them to be dependent and incapacitated. This understanding leads them to discourage their potential, conditioning them to simple domestic activities, held as appropriate to the female gender, principally when they present some disability of an acquired or congenital origin in their first years of life. From society's perspective, the roles of wife, mother and caregiver do not apply to the woman with a disability. ${ }^{2}$

In this context, it may be inferred that in the social and family context, the woman with a disability reinforces the image of a frail being due to her limitation, above all when one refers to sexuality and reproduction. It is perceived that people who live with the woman with a disability have significant importance in her life, and may present barriers to her maternal role. Therefore it is possible to presuppose that the support network influences her decision to be a mother; and, in spite of the topic under discussion being relevant, little is known regarding the support network of women with disabilities in relation to motherhood, in particular, those with physical disability.

In the light of this, the question is raised regarding what the conception is of women with physical disability regarding the support network for them in relation to pregnancy and the postpartum period. The present study aimed to investigate the conception of women with physical disability regarding the support network for the exercising of motherhood.

\section{METHODS}

This is a descriptive exploratory study, with qualitative approach, undertaken in three nongovernmental organizations located in Natal, Rio Grande do Norte, Brazil. These locales were chosen as they were accessible to the women with physical disabilities and are where they share their experiences.

A total of 12 women with disability, who had or had not experienced being mothers, participated in the investigation. The sample was obtained through data saturation, respecting the following inclusion criteria: to have a physical disability, to be in the age range between 18 and 49 years old, and to confirm the existence of limiting characteristics since early childhood (zero to three years old). The following were exclusion criteria: women who had difficulties in communicating, had multiple deficiencies, or who knew themselves to be sterile. Data collection took place in April - June 2014, through individual semistructured interviews, following an instrument constructed for this study.

The study was submitted to the Research Ethics Committee of the Universidade Federal do Rio Grande do Norte, obtaining a favorable decision under N. 618,045 in March 2014. At the time of data collection, the participants signed the Terms of free and informed consent and the authorization for voice recording. In order to ensure anonymity, the letter " $I$ " for interviewee was used, followed by a random number from 1 to 12 .

The treatment of the information took place under the precepts of content analysis, through the use of the technique of thematic analysis. ${ }^{3}$ As a result, an exhaustive reading was undertaken in order to identify the units of meaning, which were aggregated and codified, and which, in accordance with the semantics, gave rise to the categories of "recognizing the importance of the support" and "mentioning the absence of support". The analysis of the data took place in the light of the principles of symbolic interactionism, ${ }^{4}$ which guided the understanding regarding the interviewees' conception regarding motherhood, in the light of the interaction with the support network in their milieu and family. The discussion was based on the findings in the literature regarding women's healthcare in the context of reproduction.

\section{RESULTS AND DISCUSSION}

The interviewees' age varied from 25 to 47 years old, predominated women 40 years old or more. In addition to this, it was possible to observe the prevalence of those of mixed race, who were Roman Catholics, who were from the city of Natal and whose occupation was "housewife". It is emphasized that four of the women were also para-athletes. Regarding educational level, senior high school stood out; regarding family income, the prevalence was for between one and two minimum salaries (R\$ 724.00 - R\$ 1448.00) current in Brazil. Besides this, the number of people residing in the same residence as the interviewee varied from zero to five, with the presence of two to three members being most common in domestic co-existence.

In relation to the disability, the majority of the women had disabilities in one or both of the lower 
limbs, the main cause being poliomyelitis. As a result, it was inferred that for the majority, the disabilities in the population studied were acquired in origin. Regarding progeny, seven women were mothers (I3, $\mathrm{I} 4, \mathrm{I} 5, \mathrm{I} 8, \mathrm{I10}, \mathrm{I11}, \mathrm{I12}$ ) and five did not have children at the time of the interview (I1, I2, I6, I7, I9). Four of the women had experienced miscarriage (I4, I9, I11, I12).

The above-mentioned interviewees expressed their conceptions regarding the support for the mother with a physical disability during pregnancy and the postpartum, presented in two thematic categories.

\section{Recognizing the importance of the support}

The participants referred to the encouragement which comes from people with whom they live during the pregnancy and following the birth, this comprising the support network constructed by them. Even those who had not had this experience gave their opinions regarding this subject. The family support was significant in their accounts: Even the family can help, too. I know a lot of people around here who already had one [child] and nowadays the family also helps (I1); my mother called me over to her house: 'stay here for a few days, take it easy, don't clean house, let me take care of the boy', that care of a mother with her daughter (I4); I have a marvelous family. It wasn't so difficult, because of this. Because what is my parents', is mine, and what is mine, is theirs. Because of this, it was marvelous during this period (I10).

In the case of these interviewees, the experiences were positive regarding the assistance received from the family members. They had lived with the disability since their first years of life and, as a result of this, had had the support of family members throughout their lives. Therefore, the importance of the support of these extended to motherhood to respond to their needs. In addition, the family members also make themselves present at critical moments, as in the case of I4 who had a high-risk pregnancy and who needed absolute rest. This positive view of the family support is already perceived even prior to having a child, through being present in the successful situations, as in the case of I1 who had not experienced motherhood.

It is understood that a harmonious family coexistence provides security to the mothers, principally when they experience motherhood for the first time, or when their health condition requires distinct care. It is common for the female family members to mobilize in order to help them and share experiences. In the same way, mothers with a disability frequently need advice from somebody who is experienced in order to learn the first measures of care for their child, as well as to help them when they feel limited in undertaking certain activities which are specific to the maternal function.
The above-mentioned findings are corroborated by an investigation which indicated that $59.6 \%$ of women with a disability in its sample stated that family members and friends showed themselves to be positive during their pregnancy. ${ }^{5}$ Studies undertaken in Nepal and in Cameroon observed the presence of family members and neighbors making themselves available to help the women in their domestic activities, and their finances, and through providing advice. ${ }^{6-7}$

Studies addressing women, regardless of the presence or not of disability, have emphasized the importance of the maternal figure as assistance during the early times of motherhood, when the daughters generally have the responsibility of caring for both the house and the child and cannot yet balance their tasks in such a way as to achieve success. It was observed that this type of support allows the puerperal women to feel safer during the period of adaptation while they mature for the new role exercised..$^{7-8}$

In the present study, the partner was also indicated among the participants as fundamental support throughout the pregnancy and after the birth.

Thus, because a person who has a disability, depending on the disability, if she is in a wheelchair, for example, she needs the support of a partner who is understanding, who shows love both to her and to the child. [...] He also has to think [...] about both the child and her, because she is totally dependent on him for many things (I4).

There was the time when I had my second girl, and one of their aunts stayed with the older. She stayed for a while, but afterwards, when I recovered, it was only me, me and him... (I8).

In accordance with these accounts, the partner is seen as an important ally for raising the child. The interviewees emphasized the importance of knowing how to choose him, not only for his support in caring for the child, but also for her, when the disability makes her more dependent. As a result, one can observe the predominance of the desire to constitute a traditional family, and the anxiety for the sharing of responsibilities with the partner, expecting the partner to demonstrate understanding regarding the bodily limitations which the women have.

These observations agree with a study undertaken in Cameroon, in which the women admitted wanting a stable relationship and to constitute a family made up of spouse and children. ${ }^{7}$ On the other hand, other investigations have revealed that the women see their partners as a source of support and security, reducing the tension arising from the transition to the maternal function. ${ }^{9-10}$

Agreeing with the authors, one can infer the need of the women with disability to feel themselves to be social subjects capable of developing loving re- 
lationships and having active sexual and reproductive lives. However, also according to the researchers of the Cameroonian study, the members of the community in which the women were integrated encouraged the conjugal union in the perspective of the women having someone who considered them to be important. $^{7}$ As a result, there are ambiguous social ideas regarding the relationships established by the woman with a disability; some accept her as a sexual being, while others treat her with pity due to the disability.

In this understanding, in recognizing the valorization attributed by these women to the support arising from actors in their close circle, the health professional positions herself as a mediator for encouraging her to construct a support network. However, the above-mentioned approach must be made in such a way as not to characterize her as incapable. For this, it is necessary to encourage this woman to consider her care needs, the type of support which she wishes to receive, and who will attend her. ${ }^{11}$ Through having this network strengthened, she feels more confident in her maternal skills. ${ }^{7}$

As well as the people with whom they live, the interviewees also indicated the support of the health professional as important for pregnancy, giving birth, and raising a child: I didn't find this either too complicated, or difficult [...] [The health professionals] took care of me due to my disability [...] I thought that the care they provided was fairly different due to this, my disability, they were always there. Anything that I felt, it was 'ah, you can call us' [...] (I8); I've always met angels in my life. Like the doctor who didn't let me suffer even a little bit [laughing] (I12).

The health team was seen as essential for maintaining the mother and child health, being denoted as "Angels" due to the feeling of protection linked to the vocabulary, in being available for supporting the women. This occurs because the difficulties seem to be mitigated due to the caring approach and, the more accessible these professionals are, the more confidence they receive from the people whom they attend.

The professionals from the area of health who are helpful and attentive to their clientele become esteemed, and their attitudes show them as a reference for the quality of the care offered.

Studies evidence this valorization received by the health professionals due to the offering of the additional care to the women with disability, including adapting themselves according to the patients' needs and valuing counseling and dialogue., ${ }^{6,12}$

However, another study indicates that the women with disability are not always included in the decisions taken regarding the care for their health, and many believe that the health profession- als are acting for the women's own benefit, trusting in them regarding the decisions taken, even without the women's participation. ${ }^{13}$ As a result, the absence of encouragement for self-care and for autonomy in the exercising of the maternal role is recognized. In this understanding, one investigation undertaken in England indicates the need for mothers with disability to establish quality communication with the health team regarding the care for the newborn. ${ }^{14}$

Furthermore, as one can observe in the findings of the study undertaken in Sierra Leone, when the woman with a disability receives equal treatment, or, even, is attended with greater attention, she tends to be satisfied with the service, even if this is not always shown to have been altered to suit her. ${ }^{15}$ The professionals' paternalist stance may hide care which remains inadequate for this population, often caused by their lack of preparation, as the training of the health team regarding care for these women is poor. ${ }^{6}$ These professionals' training is understood to be fundamental in order to provide attendance which is appropriate for this clientele.

Regarding the exchanging of knowledge between the professional and the interviewees, it is noted that the women acknowledged seeking information and showed themselves to be aware regarding their reproductive health.

[...] Okay, here's an example. You are disabled, and you marry a person who is also disabled. And off you go, you get pregnant, and have a child with that man who is disabled just like you. [...] In my mind, I thought that if I had a child, it would be disabled. Nowadays, however, I understand that that is not how it is (I9).

Although the participant had not experienced motherhood, she placed herself in this position in order to understand that the genetic transmission of the disability to the child occurs in specific conditions. This understanding was constructed through the searching for information from other people. One can see that increasing numbers of individuals with disabilities seek to gain knowledge in health and rights, including the sharing of these with those similar to them so as to develop critical awareness, autonomy, and citizenship. Nevertheless, some women with disabilities are reluctant to ask questions, in particular to the health professionals. ${ }^{11}$ For this reason, it is necessary to promote a space in which they may be listened to carefully and made comfortable to raise their doubts.

\section{Referring to the absence of support}

During pregnancy and the postpartum, physical and emotional support was not always obtained by the study's participants. This incompleteness or absence of support from people with whom they co- 
exist socially influenced them negatively, worsening the obstacles relating to the exercising of the maternal role. Among the cases of abstention, the interviewees emphasized the family members, either through a spontaneous decision or through the imposition of the health institution: My mother was very strict. For her, a disabled person could not date. Those old-fashioned heads. [...] And it was her who cared for me, so I felt rather uncomfortable, you know? It took me a while to say to her that I was pregnant... I was scared of telling her I was pregnant [...] (I3); they took me into the unit, left all my family members outside, without any contact, without communicating anything, they sent them home and left me there alone [in the maternity unit] (I4).

One can perceive in these accounts these women's feeling of lack of support, shaped by the absence of encouragement from close family members regarding the new unprecedented situations which arose through having a child. In the case of $\mathrm{I} 3$, the fear of revealing her pregnancy to her mother became present because of her mother's disapproval in relation to the romantic and sexual relationship of a person with a disability, causing her to hide it.

Although there is, at the present time, a process of change in the social conception regarding the person with a disability, there still exists overprotection on the part of the family and ignorance regarding her sexual and reproductive health. When family members show themselves to be hostile or doubtful in relation to this context, it becomes viable for the nurse to intermediate the dialogue between the woman with a disability and her family members in a welcoming environment, such that her abilities may be discussed and understood among the members of the family. ${ }^{11}$

In relation to interviewee I4, this woman faced the isolation imposed in the hospital institution, due to her family members being impeded from being present when she was admitted as an inpatient. The difficulty in the companion's access in the hospitals during labor and childbirth of women with disability was also observed in another study, in which it was highlighted that the women giving birth met resistance from the professionals due to the institution's policy, letting them down due to not allowing a companion whom they trust as a subject of support. ${ }^{16}$

In Brazil, the presence of the companion of the parturient woman's choice is stipulated by law. ${ }^{17}$ However, obstacles continue to exist to the implementation of this in the health institutions. In one study undertaken in Rio Grande do Norte, Brazil, the nurses interviewed considered facts which hinder the presence of the companion during the process of birth, namely: absence of standardization and of institutional encouragement; the physical structure of the inpatient unit being inadequate for accomodating all the actors involved in the birth and what the professional is willing to permit, above all the professionals from the medical area. In brief, there persists the medicalization of birth, in which the woman is a passive subject of the event and depends on the professionals and institution, her own will ceasing to prevail. ${ }^{18}$

Due to the above-mentioned institutional obstacles, the parturient woman can suffer psychoemotional consequences, negatively influencing the intrapartum period. According to findings in the investigation undertaken in England, 19\% of the women with disability who participated in the sample mentioned feeling alone and worried during parturition, while among those without disabilities, the percentage was $16 \%{ }^{14}$

Besides the lack of support, the account below, from interviewee I4, leads one to consider that she felt dissatisfied with the attendance she received, as this was not adequate in the light of the experience of losing her child. This fact was aggravated by the professionals' suspicion that she had provoked the miscarriage.

At no point did they put me on a drip, they didn't apply anything. They just took me to the pre-labor room and put me there, because they had those suspicions that I had caused the miscarriage. In this way they treated me with disdain. [...] And then my, social worker, at the time, I don't know if she was a social worker, came and said that my child would be sent for laboratory tests. She didn't ask if I wanted that to happen, or whether I wanted to take her for burial [...] If I had thought in those days the way that I do now, I would've sued the hospital, I was very badly treated there, very badly treated. [...] It was my first child, and you go through all of that, and also get treated with disdain in a hospital, it's not easy, not everybody could take that (I4).

The experience of interviewee I4 in the hospital institution leads one to consider the omission of assistential and psychoemotional support, an attitude which is contrary to the bioethical conduct nowadays argued for. This is institutional and gender violence against her condition as a woman and a person with a disability, within the perspective denominated obstetric violence.

In the above-mentioned context, the health professional places herself in the hierarchical position of holder of knowledge, asserting the value judgment in order to exercise dominion and oppression over the vulnerable patient. The root of this problem may be in the reproduction of the social values justified as necessary, leading to the banalization of the violence per se. ${ }^{19}$ In spite of the unilateral information of what occurred, based on the interviewee's report, it is understood that this case goes beyond what is 
termed obstetric violence, coming to be a punitive expression regarding the act of abortion.

The omission of support from the professionals has also been found in other studies, in which the participants reported difficulties relating to the clarifying of their doubts and to the provision of appropriate support, principally for those with sensory and mental disabilities, leading to a feeling of loneliness. ${ }^{7,16}$ The suppression of care, whether intentionally or not, impacts on the sexual and reproductive life of the women with disability, failing to detect possible problems during the pregnancy and parturition. ${ }^{13}$

During the discussion on the absence of support, the partner was also mentioned in the accounts of the women with disability who experienced motherhood: [...] Sometimes you have a child with him [the partner], and some go and leave you. Because they think you don't have the ability to be a mother, with the disability that you have, they think you're nobody [...]. that you will not be a good mother because of your physical disability, that your mind isn't in the right place to be a mother, to bring up the child better (I9); bringing her up is not easy, because after eight months, her father separated from me. So I had to struggle, honestly, of course. Working, in order to be able to raise her (I10); When I fell pregnant, I wasn't happy because I did not live with his father, my son, during this time, became even more difficult (I3).

In the above-mentioned accounts, the women mentioned difficulties in taking motherhood forward without the support of their child's father. The separation from the partner was shown to be more difficult among the women with a disability, and the meaning of the absence of this support is stronger among those who need to perform, alone, the role of mother and provider. In addition to this, one of the interviewees indicates prejudices from the partner, due to her disability and the doubt raised regarding her ability. In this way, social stigma also influences her relationships and destructures the family construction.

The women wish for a stable romantic relationship, nevertheless, they may feel limited after marriage, not only by the disability, but by the social isolation which occurs, sometimes, in the light of the prejudice of people from their community. ${ }^{7}$ In the light of this, it is considered that the professional from the health area can bring the partner to the consultations, so that he may participate along with his wife in the decisions relating to the wish to have a child, and to his role in the pregnancy, birth and fatherhood. Furthermore, it is necessary to promote dialogues and actions with other social sectors, with the object of mitigating the stigmatization among members of the community regarding the sexual and reproductive health of the population in question.
Still on the subject of the absence of support, the people with whom the women with physical disability have some close bond were also presented as another important source of omission of encouragement in relation to their ability to be mothers. Often, this occurrence was perceived through the expressions of surprise and disbelief, as described in the following accounts: That's how it was with my first pregnancy. When I fell pregnant, when my belly began to grow, everybody... It was difficult for anybody with whom I had contact, apart from the people in my family who... never had this. But, the people at work, or where I went out, everybody would say 'what, you're pregnant? You, a disabled person, pregnant?! How can you... and when this baby grows, is born, is he going to have a disability too?' (I11); Even the people there in the countryside, when I went back there, I would say 'Ah, I'm getting married'. 'A [tone of surprise] what do you mean, get married?! You're disabled!? How you going to have a child? How are you going to carry the baby to full term?' (I12); [...] 'And are you going to be able to care for the child?'. The answer which I give - I hold my tongue, that's what I do, I don't answer. Because if I were to answer back, I would be rude. That is why I prefer to stay silent. Many people think like this - 'Because she was born like this, she won't be able to do anything in life' (I1).

The interviewees described the responses they received from colleagues at work, acquaintances from their home cities, and acquaintances from everyday life, when they found out about the decision to become mothers. The reaction in relation to the reality of the woman with disability taking on motherhood placed a negative meaning on their wish. The disbelief in their ability can generate emotional strain and even doubts relating to their choice.

This was also observed in the study in Cameroon, when the community members showed concern and shock due to the pregnancy of women with disability. Such reactions affected the pregnant women, leading them to interact less with the community. The social context of disapproval influenced them negatively, the women responding to this manifestation through isolation and suffering. ${ }^{7}$ Furthermore, other authors' findings have revealed that the people with whom the women with disability coexist may consider them to be selfish for wishing to become mothers, in the light of the possibility of hereditary transmission. ${ }^{12}$

The social judgment is inevitable in the light of the stigma, giving rise to conceptions of vulnerability, inability and dependency. However, it may be observed that the functionality of the parenting among people with disability does not differ in relation to those without disabilities. ${ }^{20-21}$ Hence, it is notable that the lack of awareness regarding sexual and reproductive health intensifies the stigma. 
In the face of peoples' skepticism, the interviewees in the study in question insisted on fulfilling themselves as mothers, upholding before the others their maternal and womanly ability. However, it is worth emphasizing that the fears and social disapproval themselves are capable of interfering in their decision..$^{21-22}$

Therefore, it is understood that people's negative opinions regarding being a mother with a disability can contribute to the woman revising her own meaning of motherhood. The external influence of people with whom she is close or with whom she coexists is shown to be important in her conception of being a woman and a person with a disability. As a result, there occurs the internal process of reconsiderations regarding her conception, reappointed her own conduct and her definitive decision regarding the maternal role.

\section{FINAL CONSIDERATIONS}

Based on the accounts analyzed, one can observe that the interviewees have a support network which enables them to soften the adverse feelings, and which contributes in the exercising of the maternal function, when they finds themselves limited by their morphofunctional condition. Sometimes, however, this support may be absent, causing negative impacts regarding motherhood and contributing to the woman reviewing her own meaning of the event under consideration.

Those who have not experienced motherhood showed that they had the same conception as the others regarding the support of the people with whom they coexisted. In this way, the meaning of the support network is constructed before the event of becoming a mother and is made real in the light of their experience. In addition to this, the women with disability interact between themselves and exchange experiences which influence the meaning constructed regarding motherhood.

In this context, the nurse, along with the team, can promote the reproductive health of the person with a disability before the population, by integrating her into the actions undertaken by the health services, particularly in Primary Care. In understanding the sociocultural contexts and the importance of the family and the community in the decision of the woman with a disability to become a mother, the nurse can, in her work process, involve the support network in the ambit of reproductive health care.

For this, the undergraduate courses in the biomedical area and the health services must promote knowledge regarding the woman with a disability who wishes to become a mother, so as to form/ improve health professionals who are trained to assist her holistically. In this way, the present study can contribute to changing the conduct necessary. Furthermore, it is necessary for there to be public policies geared specifically to the needs of this population contingent.

As a limitation of this study, it is emphasized that the choice of the women with physical disability was restricted to those associated in nongovernmental organizations. This is justified by the absence of data in the information system, which supported the localization of possible participants in other institutions. Additionally, there was no distinction between women who were mothers and those who had not experienced this role. Therefore, it is recommended that this study related to the above-mentioned population should be broadened, with the aim of contributing to reproductive health, above all, in the area of Nursing, including encompassing other types of morphofunctional limitation, so as to provide new support for the quality of care to the woman with a disability.

\section{REFERENCES}

1. Secretaria Nacional de Promoção dos Direitos da Pessoa com Deficiência (SNPD). Cartilha do Censo de 2010 - Pessoas com deficiência. Brasília (DF): SNPD; 2012.

2. Nicolau SM, Schraiber LB, Ayres JRCM. Mulheres com deficiência e sua dupla vulnerabilidade: contribuições para a construção da integralidade em saúde. Cien Saude Coletiva [online]. 2013 Mar [cited 2013 Mai 19]; 18(3):863-72. Available from: http:/ / www.scielo.br/ pdf/csc/v18n3/32.pdf

3. Blumer H. Symbolic interactionism: perspective and method. Califórnia (US): University of California Press; 1986

4. Bardin L. Análise de conteúdo. Lisboa (PT): Edições 70; 2011.

5. Lee EO, Oh H. A wise wife and good mother: reproductive health and maternity among women with disability in South Korea. Sex Disabil [Internet]. 2005 Fall [cited 2014 Jul 01]; 23(3):121-44. Available from: http://link.springer.com/content/ pdf/10.1007\%2Fs11195-005-6728-y.pdf

6. Morrison J, Basnet M, Budhathoki B, Adhikari D, Tumbahangphe K, Manandhar D et al. Disabled women's maternal and newborn health care in rural Nepal: a qualitative study. Midwifery [Internet]. 2014 Nov [cited 2014 Dez 26]; 30(11):1132-9. Available from: http:/ / www.midwiferyjournal.com/article/S0266-6138(14)00092-8/pdf

7. Bremer K, Cockburn L, Ruth A. Reproductive health experiences among women with physical disabilities in the Northwest Region of Cameroon. Int J Gynecol Obstet [Internet]. 2010 Mar [cited 2012 Set 02]; 108(3):211-3. Available from: http:// www.sciencedirect.com/science/article/pii/ S0020729209006018 
8. Afiyanti $Y$, Solberg SM. "It is my destiny as a woman": on becoming a new mother in Indonesia. J Transcult Nurs [Internet]. 2014 May [cited 2014 Ago 24]; Epub ahead of print. Available from: http:/ /tcn.sagepub. com/content/early/2014/04/30/1043659614526243

9. Fernández SB, Vizcaya-Moreno MF, PérezCanaveras RM. Percepción de la transición a la maternidad: estúdio fenomenológico en la província de Barcelona. Aten Primaria [Internet]. 2013 Out [cited 2014 Set 18]; 45(8):409-17. Available from: http:/ / www.sciencedirect.com/science/article/pii/ S0212656713001315

10. Rodrigues BC, Mazza VA, Higarashi IH. Social support network of nurses for the care of their own children. Texto Contexto Enferm [Internet]. 2014 AbrJun [cited 2015 Ago 19]; 23(2):460-8. Available from: http:/ / www.scielo.br/pdf/tce/v23n2/0104-0707tce-23-02-00460.pdf

11. Smeltzer SC. Pregnancy in women with physical disabilities. JOGN Nurs [Internet]. 2007 Jan-Fev [cited 2013 Set 02]; 36(1):88-96. Available from: http:/ / onlinelibrary.wiley.com/doi/10.1111/j.15526909.2006.00121.x/pdf

12. Gibson BE, Mykitiuk R. Health care access and support for disabled women in Canada - falling short of the UN Convention on the rights of persons with disabilities: a qualitative study. Women's health issues [Internet]. 2012 Jan [cited 2013 Set 02]; 22(1):e211-8. Available from: http://www.sciencedirect.com/ science/article/pii/S1049386711001757\#

13. Phillips LJ, Phillips W. Better reproductive healthcare for women with disabilities: a role for nursing leadership. ANS Adv Nurs Sci [Internet]. 2006 Abr-Jun [cited 2013 Set 02]; 29(2):134-51. Available from: http://meta.wkhealth.com/pt/pt-core/ template-journal/lwwgateway/media/landingpage. htm issn $=0161-9268 \&$ volume $=29 \&$ issue $=2 \&$ spa ge $=134$

14. Redshaw M, Malouf R, Gao H, Gray R. Women with disability: the experience of maternity care during pregnancy, labour and birth and the postnatal period. BMC Pregnancy Childbirth [Internet]. 2013 Set [cited 2014 Jul 01]; 13(174):1-14. Available from: http:/ / www.ncbi.nlm.nih.gov/pmc/articles/PMC3848505/ pdf/1471-2393-13-174.pdf

15. Trani J, Browne J, Kett M, Bah O, Morlai T, Bailey $\mathrm{N}$ et al. Access to health care, reproductive health and disability: a large scale survey in Sierra Leone. Soc Sci Med [Internet]. 2011 Nov [cited 2013 Set 02]; 73(10):1477-89. Available from: http:// www.sciencedirect.com/science/article/pii/ S0277953611005594\#

16. Walsh-Gallagher D, Sinclair M, McConkey R. The ambiguity of disabled women's experiences of pregnancy, childbirth and motherhood: a phenomenological understanding. Midwifery [Internet]. 2012 Abr [cited 2013 Set 24]; 28(2):156-62. Available from: http:/ / www.sciencedirect.com/ science/article/pii/S0266613811000052\#

17. Brasil. Lei $\mathrm{n}^{\mathrm{0}} 11.108$, de 7 de abril de 2005: altera a Lei n-8.080, de 19 de setembro de 1990, para garantir às parturientes o direito à presença de acompanhante durante o trabalho de parto, parto e pós-parto imediato, no âmbito do Sistema Único de Saúde - SUS. Diário Oficial [da] República Federativa do Brasil, 8 abr. 2005. Seção 1, p. 1.

18. Júnior PBC, Carvalho IS, Macedo JBPO. Unfavorable institutional conditions to the presence of the caregiver: the viewpoint of nurses. Rev Pesqui Cuid Fundam [Internet]. 2013 Out-Dez [cited 2014 Set 01]; 5(4):671-80. Available from: http://www.seer. unirio.br/index.php/cuidadofundamental/article/ view/2354/pdf_945

19. Aguiar JM, D'Oliveira AFPL, Schraiber, LB. Violência institucional, autoridade médica e poder nas maternidades sob a ótica dos profissionais de saúde. Cad Saude Publica [Internet]. 2013 Nov [cited 2014 Out 06]; 29(11):2287-96. Available from: http:/ / www. scielo.br/pdf/csp/v29n11/15.pdf

20. Frohmader C, Ortoleva S. The sexual and reproductive rights of women and girls with disabilities. In: International Conference on Human Rights, 2013 Jul 1-18; Países Baixos: ICPD; 2013.

21. Signore C, Spong CY, Krotoski D, Shinowara NL, Blackwell SC. Pregnancy in women with physical disabilities. Obstet Gynecol [Internet]. 2011 Abr [cited 2013 Set 02]; 117(4):935-47. Available from: http:/ / www.scopus.com/ record/ display.url?eid=2-s2.079953175637\&origin=resultslist\&sort $=$ plf-f\&src $=$ s\& st1=Pregnancy+in+Women+With + Physical+Disab ilities

22. Rogers J. The disabled woman's guide to pregnancy and birth. $2^{\mathrm{a}}$ ed. Nova York (US): Demos Medical Publishing; 2010. 